\title{
Panel seeks fresh course for ocean research
}

\section{Virginia Gewin}

Ocean scientists in the United States have been waiting three years for a study, commissioned by President Bush, that they fervently hoped would revitalize the institutions that support their work. This week they got their report - but it remains unclear whether the revitalization will take place.

The US Commission on Ocean Policy, chaired by James Watkins - who served as energy secretary under Bush's father recommended 200 reforms in the document it was expected to release on 20 April. The report calls for the establishment of a National Ocean Council at the White House, to coordinate the $\$ 7$ billion that the government spends each year on ocean management, research and education.

But the commission rejects calls for an independent ocean research agency to replace the National Oceanic and Atmospheric Administration (NOAA), which is part of the Department of Commerce. They say privately that strengthening NOAA is more feasible politically.

The panel calls for a doubling of ocean research funding over five years and for greater focus on ecosystem approaches to ocean management that address relationships between land, sea and air. It also says that regional councils should be set up to help manage fisheries, and that $\$ 1.7$ billion should be invested in an integrated ocean observing system, comprising satellites, buoys, sensors and computer systems, to be run by NOAA.

The commission's mandate was broader

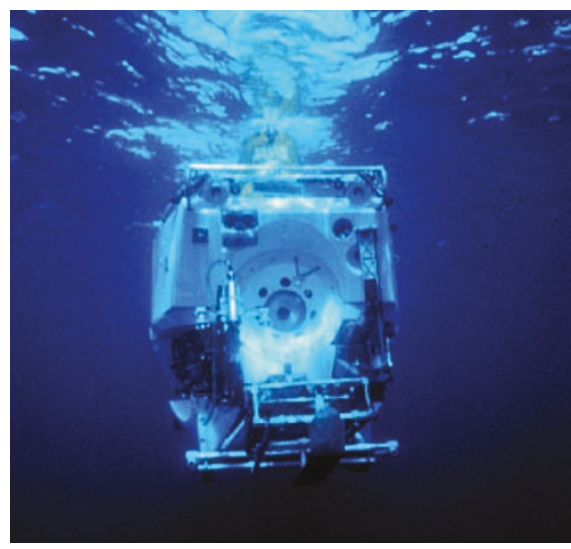

Making a splash? An expert panel has called for a revamp of US oceanography.

than that of last year's independent Pew Oceans Commission (see Nature 423, 577; 2003), which focused only on living resources, but many of the recommendations are similar. However, the Pew panel backed the idea of setting up an independent agency to supplant NOAA.

"If the administration doesn't capitalize on both commission reports, it will be a real disservice to the nation," says Jane Lubchenco, a marine biologist at Oregon State University and member of the Pew panel.

Some fear that the Watkins report, which took longer than expected to appear, may have arrived too late to influence policy under the Bush administration. Nonetheless, advocates of ocean research are pursuing legislation in both the House and the Senate to set up the National Ocean Council and implement other aspects of the report.

James Connaughton, chairman of the White House Council on Environmental Quality, says the Watkin commission's work has already spurred the administration to action. He points out that it recently sent officials to an international summit aimed at implementing an integrated global observation system, and sent legislation to Congress calling for more effective, market-based management tools for fisheries.

Ocean research supporters in the Senate have already passed bills on coastal development, the ocean observing system and research on the relationship between oceans and human health, and have introduced an ocean-exploration bill. And both houses will hold hearings on the more comprehensive Big Ocean Bill, known affectionately as Bob, before the end of the month.

But none of this activity will necessarily give ocean explorers the kind of public prestige to which they aspire. "We're spending billions to find out if there was water on Mars when we know there's water on Earth but don't know what shape it's in," says Jim Greenwood (Republican, Pennsylvania), co-chairman of the House Oceans Caucus.

But Watkins is optimistic that his panel's report will strengthen US ocean research in the long term. New approaches and investment are urgently needed, he says. Watkins doesn't think that other priorities in Washington - such as the war on terrorism will bury his report. "We're a big nation," he says. "We ought to be able to walk and chew gum at the same time."

\section{Japanese Nobels fail to inspire interest in science}

David Cyranoski, Tokyo

Four Nobel prizes and various initiatives to popularize science don't seem to be making much difference: a survey just released by Japan's science ministry says that the public is losing interest in science and technology.

Just $51 \%$ of the 2,084 adults polled earlier this year expressed an interest in science - a fall of $9 \%$ since the last time the survey was done in 1998.

Better results might have been expected in a country that nearly doubled its number of Nobel laureates in the sciences, from five to nine, officials at the ministry say. They are especially frustrated as they have tried to popularize science in various ways. $¥ 3$ billion (US\$28 million) has been invested in the National Museum of Emerging Science and Innovation in Tokyo, which opened in July 2001, and science-based

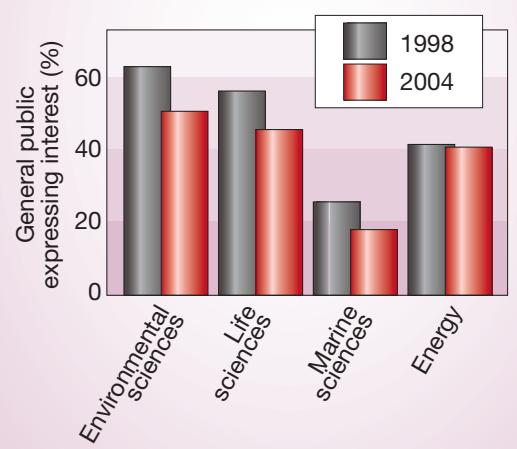

television shows have been launched.

But according to the survey, which was released on 10 April, the number of people interested in what scientists have to say has been declining. In 1998, most of those who said they would not attend public lectures on science said it was because they found them difficult to follow. In the latest poll, only one-third objected to the difficulty level — but almost $60 \%$ said either that they had no interest or that science did not seem relevant to their lives.

Noyuri Mima, a former cognitive scientist and the director of research and development at the new Tokyo museum, says she finds the results troubling. "Researchers get huge amounts of money but they do not try to explain what they do in a way people understand," she says.

Nonetheless, Mima is optimistic that innovative efforts such as the museum will pay off in the battle for the hearts and minds of the next generation. "We are trying to show the underlying process of science as it is happening," she says. "This will attract young people, but it will take time." 